\title{
Swedish Principals' Understanding of the Concept: Education Based on Research and Proven Experience
}

\author{
Stephan Rapp ${ }^{1} \&$ Tomas Kroksmark ${ }^{1, *}$ \\ ${ }^{1}$ School of Education and Communication, Jönköping University, Sweden \\ *Corresponding author: School of Education and Communication, Jönköping University, \\ Sweden. E-mail: tomas.kroksmark@ju.se
}

Received: December 11, 2016 Accepted: February 2, 2017 Published: March 16, 2017

doi:10.5296/ije.v9i1.10428 URL: https://doi.org/10.5296/ije.v9i1.10428

\begin{abstract}
This study aims generate new knowledge concerning how principals in primary and secondary education in Sweden conceive of and experience the concepts of 'research basis' and 'proven experience'. The study included in-depth interviews with eight principals. The interviews were analysed, and the results are theoretically founded in the phenomenographic life-world.

The results indicate that Swedish principals in primary and secondary schools are poorly prepared for managing schools where the education must be based on research and proven experience. The principals have no education in this area, nor do they have any co-workers who can take the responsibility to implement and/or generate research-based knowledge. An interesting question is: Does education require a specific research concept that differs from the academies definition?
\end{abstract}

Keywords: Research and Proven Experience, Principal, Primary and Secondary School, Phenomenography 


\section{Introduction}

The studies of 15-year-old pupils' scholastic attainments that the OECD/PISA has conducted since 2000 indicate that the quality of Swedish education has been declining. The study presented in December 2013 stated that Sweden has suffered greater qualitative losses in education than all of the other countries included in the PISA investigations (OECD, 2014). This finding implies that the quality of Swedish education, as indicated by 15 -year-old pupils' acquisition of mathematics, science, reading comprehension and problem-solving knowledge, has been declining continuously in all measurements from 2000 to the present.

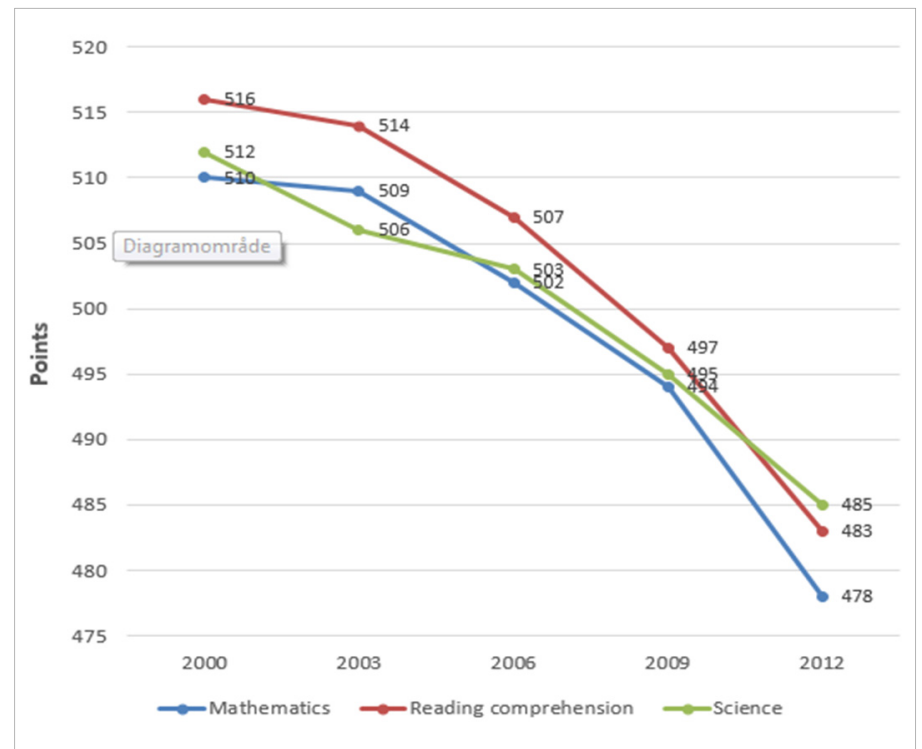

Chart 1. PISA Results for Sweden, 2000-2012. (www.skolverket.se)

To address the increasingly poor quality of education, the Swedish Government has implemented extensive reforms in recent years; however, few of these reforms are supported by research. It is believed that there is a lack of relevant research, and above all, that educational research has failed in its mission to provide teachers with specific knowledge that might result in a higher quality of education (Bryk, Gomez, Grunow \& LeMahieu, 2015).

Nevertheless, the school reforms of the $21^{\text {st }}$ century are the most extensive ones that have been implemented in the history of Swedish education. Within the framework of these reforms, a new Education Act (2010:800) was enacted in 2011. An important point of this Education Act is stated in Chapter $1 \S 5$ : "Education shall be based on research and proven experience". The formulation implies that in a clearly decentralised Swedish education system, instruction must be based on current research and documented proven experience. This is the wording of the Act, which seems to be uncommon from an international perspective. An exception is the No Child Left Behind Act (SEDL, 2016). The objective of research-based teaching is that tests should show an improvement in the quality of education.

Primary and secondary education that must be based on research and proven experience is entirely new to working teachers and principals. Traditionally, the teaching and school 
leadership professions have been based on an explicit (Chang, 2008) and sometimes an implicit discourse (Polany, 1966) combined with a traditionally weak documentation culture (Hirsh, 2013). Until recently, teacher training in Sweden did not include any scientific work. Accordingly, most Swedish teachers have never participated in scientific work themselves. It is difficult to find any direct research basis in Swedish schools, and teachers and principals who conduct research are very rare. Additionally, Valencia, S., Martin, S., Place, N. \& Grossman, P. (2009) and Hegender (2010) argue that teachers are the academically educated professional group that exhibit the least interest in research on and a research basis for their own profession.

The Education Act also states very clearly that it is the principal's responsibility to ensure that the quality of educational activities be held at the highest possible level, a mandate that includes the responsibility for ensuring that education is based on research and proven experience. Simultaneously, in terms of the curriculum (the Swedish National Agency for Education, 2011), the principal is the school's pedagogical leader, which includes a responsibility for the school's outcomes (Rapp, 2010). Against this background, it is important to study how principals in primary and secondary schools conceive of the act's stipulation that "Education shall be based on research and proven experience", particularly whether the text of the law is connected both to the mission of education and to a political hope for a better educational system. It is the principal who is responsible for conforming to the act's requirement and ensuring that research forms the basis of teaching and learning so that the end results show improvement.

This study aims at generating new knowledge of how principals in primary and secondary education in Sweden conceive of and experience the concepts of 'research basis' and 'proven experience'. The questions that will contribute to the fulfilment of this aim are

- What does 'research basis in primary and secondary schools' mean to the principals of such schools?

- What does 'proven experience in primary and secondary schools' mean to the principals of such schools?

\section{Central Concepts}

The three concepts that are central to this study are education, research and proven experience. Education refers to the activities in all schools for children and young people (ages 1-19 years), the compulsory levels for students with intellectual disabilities, the special schools for students with intellectual disabilities, the schools for the Sami, the Swedish language programmes for immigrants and adult education programmes. The concept of education is extensive in the preparatory work of the Act, which includes such discussions as 'teaching shall be based on research and proven experience, 'learning shall be based on research and proven experience' and 'the activity in school shall be based on research and proven experience.' The act states that education shall comprise both the subjects, theoretical content and the methods used to teach it. 
Etymologically, the term education derives from the Latin word èducātiō, which means 'bringing up, breeding, rearing and ēducāre, which means 'to bring out or to nourish'. From a conceptual perspective, education has been defined since classical antiquity by a number of philosophers and pedagogues. Among these, we find Aristotle, who argues that 'Education is the creation of a sound mind in a sound body' (Sahu, 2007, p. 14). Much later, Johan Heinrich Pestalozzi gives his definition: 'Education is the natural, harmonious and progressive development of man's innate powers' (Aggarwal, 2007, p. 6). In the last century, John Dewey also discussed the concept of education, saying that it is ' ... that reconstruction or reorganisation of experience which adds to the meaning of experience, and which increases ability to direct the course of subsequent experience' (Dewey, 1985, p. 76); furthermore:

This process begins unconsciously almost at birth and is continually shaping the individual's powers, saturating his consciousness, forming his habits, training his ideas, and arousing his feelings and emotions. Through this unconscious education the individual gradually comes to share in the intellectual and moral resources which humanity has succeeded in getting together. He becomes an inheritor of the funded capital of civilisation. (Dewey, 1897, p. 77).

Encyclopaedic definitions of what education is also vary, but we can establish the following generally accepted definition:

Education is a continuous and lifelong process. It starts from the womb of the mother and continues till death. It is the process of development from infancy to maturity. It includes the effect of everything which influences human personality (Nef, 2014).

The Swedish legislation requiring education to be based on research and proven experience does not seem to have a philosophical/pedagogical foundation, nor does any research-based assumption form the basis of the act's definitions (proposition 2009/10:165). It could be that education in the $21^{\text {st }}$ century viewed in terms of political efficiency, which characterises knowledge and skills in relation to a global knowledge race;(Note 1) from this point of view, education is temporally determined and has fixed resources at its disposal. Against such a background, education could be considered a political project that has a predetermined beginning and end and politically influenced objectives whose results must be evaluable and comparable.(Note 2) In such a context, education can be defined as a temporally limited, rational, institutionalised system managed by objectives with measurable and comparable knowledge effects (Kroksmark, 2011).

The second central concept in this study is research-based. The word research was coined in the $16^{\text {th }}$ century (1577) and is derived from the French word recherche, which means 'search', and the term rechercher, which means 'to seek' (cf. Merriam Webster, 2014). In our own age, the concept has taken on different meanings depending on the discipline or area of science using the term. 
At an overarching level and common to all researchers is the demand for a systematic basis, theoretical and methodological clarity, a critical attitude, and total openness in the process. These factors provide opportunities for external critical examination and clear evidence that the results based on data. A decisive criterion of research is that it is supposed to solve a problem or explain connections in a previously unknown way. It takes it points of departure from widely different assumptions of an ontological or epistemological nature. The differences among scientific, mathematical, medical and technological research compared to social science, the humanities and educational science, for example, are striking, as is again the difference between the aesthetic sciences and practitioner research. The Swedish Education Act talks about 'research-based' practices in general, which imply a total openness in the interpretation of the concept of 'research' when it is applied to public education.

Proven experience or tested experience is the third concept that is important in the new Swedish Education Act. Etymologically, the word proven derives from the Latin probus, which means 'good', and probare, denoting 'test', 'approve', or 'demonstrate'. The word experience derives from the Latin experiri, which corresponds to the English try', and experientia, which corresponds to 'trial' or 'test'. In the sciences, the phrases proven experience and tested experience are used conceptually as synonyms and in the sense that something has been tried repeatedly in professional practice in controlled (experimental) forms that require documentation (cf. SERC, 2014). The close relationship between proven experience and evidence-based practice lies the professional's weighing her/his expertise with the best available knowledge, the individual situation, experiences and wishes when making decisions about a given measure.

The term proven experience is stated in the act as a requirement for educational content and methods in Swedish schools, but the question here is how principals in primary and secondary schools understand and describe the content of this requirement.

The Swedish school curriculum (Lgr 11) is national and encompasses all state and independent primary and secondary schools. The overall curriculum contains three parts: 1 . The fundamental values and tasks of the school; 2. The overall goals and guidelines for education; 3. Syllabuses, which are supplemented by knowledge requirements.

(1) In the Swedish school curriculum (Lgr 11), one can see that the national school system is based on democratic foundations and that the Education Act (2010:800) stipulates that education in the school system aim to help pupils acquire and develop knowledge and values. The act further stipulates that the education provided should be equivalent, regardless of where in the country it is provided. National goals specify the norms for equivalence ( $\operatorname{Lgr} 11$, pp. 9-13). One aspect of this national equivalence is that education in every school has to be based on research and proven experience.

(2) The syllabus consists of 20 subjects, each of which includes the purpose of the subject, the subject's main content, and the knowledge requirements for school year three, school year six and school year nine. National tests, which are not exam samples but part of the teacher's information about the student, are administered during school years three, six and nine. The Government decides for which subjects 
and in which school years these national tests should be carried out (www.skolverket.se).

The requirement that education be based on research and proven experience was not widely debated when the act was instituted, and there were no discussions of implementation strategies at that time. Fixsen et al. (2005) argues that implementation is a process, not an event. Further, implementation will neither happen all at once nor proceed smoothly. The absence of implementation strategies may result in the law having no or little impact on school activities. To reinforce the implementation efforts, a state-appointed investigator was given the task of establishing and implementing a new authority, the Swedish School Research Institute, in 2014. The task of this authority is to disseminate research that can contribute to increased knowledge of effective methods in schools. The goal is to improve the performance of schools (Kommittedirektiv 2014:7).

In Sweden, there are two areas that the law dictates should base their work on research and proven experience: higher education and health care. With the Education Act (2010:800), it follows that primary and secondary schools are subject to the same requirement. Laws are political works based on contemporary national and international social developments, among other factors. However, the preparatory work for the act (prop. 2009/10:165) does not show that the legislator had sought out international examples. If he had, he could have found some precedents in the English debate that started in the mid-1990s (Hargreaves 1996, Hammersley 1997, Elliott 2001). This debate concerned the same concepts that are currently legally required to be implemented in Swedish schools.

\section{Previous Research}

A search of the Education Resource Information Centre (ERIC) and UNESCO/OECD/EUROSTAT (UOE) databases yielded no examples of Swedish principals conducting research on their own work and no studies of how principals in primary and secondary schools view local school improvement based on their own research. This differs from the global context, in which one can find many studies conducted by principals and teachers. On the whole, in Sweden, there is no extensive information on how research is conducted in teachers own class-rooms or in the local schools. John Dewey made an early effort in 1929; in the book The Sources of a Science of Education (Dewey, 1929/1984), under the heading 'The Teacher as Investigator' he discusses teachers' opportunities to contribute to research: "It seems to me that the contributions that might come from class-room preachers are a neglected field; or, to change the metaphor, an almost unworked mine" (Dewey, 1929/1983, p. 23). He argues that teachers should be included in research because of their proximity to the pupils, but he also notes that teachers might constitute a problematic bridge between research and the pupils:

[...] teachers are the ones in direct contact with pupils and hence the ones through whom the results of scientific findings finally reach students. They are the channels through which the consequences of educational theory come into the 
lives of those of the school. I suspect that if these teachers are mainly channels of reception and transmission, the conclusions of science will be badly deflected and distorted before they get into the minds of the pupils. (Dewey, 1929/1983, p. 24).

Dewey describes research in the classroom as dichotomous. One part involves viewing principals and teachers as consumers of research results whose chief task is to apply the results to the practice of teaching. The other part involves viewing principals and teachers as producers of research-based knowledge, whose task is also to generate practice-based knowledge based on research and proven experience.

Colleen McLaughlin (2004) argues that for as long as research on education has existed, teachers have been regarded as consumers of research-based knowledge. This is also how the Swedish National Agency for Education (2014) interprets the Education Act's demand for research-based and proven experience. Rudduck (1992, p. 200) notes that in all essential ways, research in the classroom is dictated by researchers in the universities. For this reason, principals and teachers have seldom been offered opportunities to conduct research of their own in the classroom, which has resulted in proven experience seldom forming the basis of educational choices in schools.

Dewey's suggestion that teachers should do research in their own everyday work was later adopted by several researchers. Lawrence Stenhouse coined the term "teacher-as-researcher" (Stenhouse, 1975). He states the reason for this term in the following way: "It is teachers who in the end will change the world of the school by understanding it" (1981). Andy Hargreaves is of the same opinion: "One alternative is to treat practitioners themselves as the main (but not only) source for creation of professional knowledge' (1999, p.125). McLaughlin (2004) claims that in England, it was John Ellliot, in his book Action Research for Educational Change (1991), who argued for the first time that action research is a distinct form of research in the classroom that not only studies the practice of education but transforms it into something better.

Stenhouse lists three possible areas for teachers to conduct their own research: "The commitment to systematic questioning of one's own teaching as a basis for development, the commitment and the skills to study one's own teaching and the concern to question and to test theory in practice" (Stenhouse, 1975, p. 143). Rapp \& Kroksmark (2017) show that successful research implemented by teachers in their professional practice is a matter of studying, via research interviews (Kvale, 1994), what the pupils do when they learn what they should learn at school and that this knowledge should form the basis for choosing the contents and methods of teaching. We can see that the discussion of the degree to which teachers can and should be consumers and producers of research-based professional knowledge assumes different positions. The issue of quality has been prominent because it is obvious because it was not a part of their training, that a large proportion of Swedish teachers do not possess the type of scientific competence required to implement the new knowledge being developed by researchers in their profession.

Worldwide, teacher education is relatively similar (Cochran-Smith \& Zeichner, 2005; Cochran-Smith et al. 2008); in most cases, there are no courses in which students learn to 
implement research specific to teaching and education. Consequently, an important competence provider is already lacking in the teacher education. For a number of years, Finland has attained excellent results in the PISA investigations. The reasons have been frequently discussed by many researchers (cf. Darling-Hammond, 2010; Sahlberg, 2009). One decisive reason for Finland's good results is suspected to be research-based teacher education (Toom, et al., 2008; Kansanen, 2014). Among other things, Finnish teacher education contains a module in which the students learn to conduct research at a master's level:

The master's thesis conducted at the end of the study programme is an independent but supervised research project. It could also be seen as the integration of the theoretical knowledge base or theoretical knowing and the use of appropriate data collection and analysis procedures (Toom, et al., 2008, p 4).

Scientific knowledge and experiences conducting one's research in the education field are considered decisive for the quality of the Finnish education, and the outcomes of this approach can be observed in the good knowledge results that Finnish students attain on international tests. Kansanen (2014) describes in detail the relationship between teaching and research and makes a distinction between basic level and conceptual level teaching and research. On the basic level, teachers are consumers of researched-based knowledge. They learn to implement such knowledge in their profession. On the conceptual level, teachers are producers of researched-based knowledge through their own research; conducting research allows teachers to become experts on practice research in schools and experts on the content they focus on in their research.

\section{The Implementation of the Study: Theory, Method and Implementation}

This study aims to understand and describe principals' experiences or conceptions of the concepts of 'research-based' and 'proven experience'. We chose an experience-based theory to support the study's method, implementation and analysis. The object of the study (the research basis and the proven experience) is also integrated into a concrete educational experience in which principals lead and work in an activity that is social and has clear objectives and that also has clear boundaries in terms of time and resources. Principals' work is therefore characterised by their lived experience (van Manen, 1990); it is implemented within a context, among people, in a professional culture subordinate to a certain societal order. This implies that the theoretical points of departure must be examined within the framework of an experiential philosophy that does as great justice as possible to the concrete everyday school situation (cf. Heidegger, 1927; Gadamer, 1975; Bengtsson, 2013).

The life-world is established within the phenomenology that Martin Heidegger (1927) developed. In this study, we have taken as our starting point the context of the everyday school situation, in particular those in which the concept of research-based and proven experience should be living and concrete. Principals are thrown into this context through no fault of their own but are thrown in in the sense that they act. The life-world is concrete and 
lived. What we think that we know is a consequence of our lived experiences. The life-world is collectively borne but individually experienced; that is, it is subjectively handled and perceived. This means that we always perceive something and that its content is qualitative in nature. Therefore, data were collected through research interviews (Kvale, 1983; 1994) and analysed via the phenomenographic (Marton, 1981) method of analysis, in which the result consists of qualitatively different descriptive categories.

The data were collected from eight principals working at different primary and secondary schools in Sweden. They were randomly selected from three municipalities that were working with some form of research basis for education. The number of interviews was determined using what Steinar Kvale defines as the saturation effect, which implies "having conducted so many interviews that more would not produce any essential new knowledge" (Kvale, 1997, p. 98). The interviews are thematically organised with completely open questions throughout. Taken together, the interviews lasted for six hours. All of the interviews were conducted in the local school and during working hours. The interviews were audio recorded (Mp3) and transcribed word by word. The interviews were analysed through both listening to the recordings and interpreting the text of the transcriptions. The analysis focused on the qualitative similarities and differences in the principals' statements about their conceptions of the main issues.

The analysis was based on a model developed by Bengtsson \& Kroksmark (1994) that has been used in previous studies (Kroksmark, 1995; Kroksmark, 1996; Johansson \& Kroksmark, 2004). The model differentiates analytically among the principals' conceptions, which are sorted into four distinctly different levels:

Level 1. Spontaneous and everyday-based conceptions that unreflective and are taken for granted.

Level 2. Acquired and learnt conceptions, such as we have learnt at school or in various educational experiences.

Level 3. Systematically based conceptions, which refer to research and proven experience.

Level 4. Reflection and critically based conceptions that have philosophy as their point of departure.

The results were formulated as descriptive categories, a form of phenomenographic narration (Kroksmark, 2014).

Janesick (1998) claims that "validity in qualitative research has to do with description and explanation, and whether a given explanation fits a given description. In other words, is the explanation credible?' (p. 50). The study is validated on content level in every concrete interview situation. In a qualitative research interview, the interviewer continuously examines the validity of the responses by correcting and guiding questions in a way that secures validity. Furthermore, it can be noted that generalisation is not considered as a central part of this study; rather, the transfer of concepts is of greater importance here. Transferability means 
that the results can be applied in another situation. At that point, the person considering the results makes the decision about their transferability (Wibeck, 2000; Rapp, 2010).

Transferability should replace applicability, or external validity, as conventionally conceived (Lincoln \& Denzin 2004, p 173).

\section{Results}

The results are presented in qualitative descriptive categories based on statement analyses performed by the principals within the framework of the given themes declared in the aim of the study. From these themes, we extracted five content areas within the framework that we had made using the descriptive categories.

At an overarching level, the study shows that principals in primary and secondary schools are very poorly prepared to manage schools where according to law, the education must be based on research and proven experience. The principals have no education within that area, nor have they any co-workers who can take the responsibility for implementing and/or generating research-based knowledge. The result also shows that the principals try to find teachers who have a strong social trust with one another rather than ensuring that specific research competence exists when research basis and the proven experience are made clear in the individual school. Furthermore, the principals report that they completely lack support from the parent body; i.e., from the municipal and/or state level as regards the research basis.

The result also shows that the principals have a very positive view of research in general as something that is very important in a modern society. However, when research must be included as a component of education or of the teaching profession, there is great hesitation. The stated reasons are that schools as workplaces are very different from other activities and that the existing educational research is not relevant.

\subsection{The first research question: What is the research basis in primary and secondary schools according to the principals in such schools?}

Principals' conceptions about the research basis in schools differ considerably; however, the main theme indicates that their knowledge about research in general and about educational contexts in particular is weak and remains on an everyday level. At the same time, and paradoxically, the principals have great confidence in research-based education. Their general opinion is that the quality of education would improve if research were systematically introduced and implemented in the classroom.

The qualitative differences among the principals' conceptions are presented as descriptive categories based on the analytical model presented above.

Category 1. A research basis is unnecessary at school.

This category is constructed through the principals' statements that educational research does not provide teachers or schools with usable knowledge (Level 1). The difference between the 
academic research and the extensive complexity of schools is so great that teachers and principals do not want to conduct research.

... here they had, I'd like to say, a rather dreary outlook on research [...] they sniffed a little at science, they sniffed a little at the Agency for Education [...] well, sort of, if research had said it, then we'll do the opposite because we know the score (Principal 2).

The statement implies a strong repudiation of the research being conducted by researchers on and for education and teachers. Teachers may even obstruct and hence completely reject the results of research. Such opinions make it impossible for education to be based on research. This opinion is explained by the prevalent school culture and the fact that this study represents the first time that such activities have been examined.

...it's the culture; it's about schools being in their culture and that it has worked well. [...] So that it has not been questioned either. From somebody from outside who has looked into the school, 'what are you really doing there?' (Principal 5).

The framework of this category also asks why teachers in schools have not before been more interested in the research basis. How can research be conceived of as unnecessary by an academically educated professional group? None of the interviewed principals mentions this as a problem. Instead, it is observed as a good thing that the political decision-makers have initiated the demand for a research basis in the new Education Act:

It's really a bit strange that this has not been legislated before, this demand for a research basis. It's really a bit remarkable (Principal 3).

Category 2. Research is difficult to understand.

The principals state consistently and without exception that research is difficult to understand, assimilate and implement in teaching. This conception is the result of insufficient knowledge of what research and science are and of none of them having any experience conducting their own research (Level 1):

... but it's still difficult to formulate what it is exactly (Principal 2).

What is a research basis and...there are many who are still discussing it. What does it stand for? (Principal 3).

Because we haven't talked about science and research in that way. We haven't made it a concern. Instead we have run things on proven experience (Principal 5).

The prevailing uncertainty among principals about the research basis is chiefly said to be the result of weak teacher education. However, another reason is that few people want research-based knowledge to serve as a foundation for teaching and that at the central level, in the municipality or the school authority, there are no opportunities for further education. In addition, no efforts have been made that might increase teachers' and principals' knowledge of how research can form the basis of the education in schools. 
Within the framework of this category, the principals also state their opinions on the issue of responsibility. Who decides that research must constitute the basis of the education in the local school? At the same time the principals are critical of the municipality and the central authorities, they state teachers are also responsible for enacting research-based approaches:

... the individual teachers have a very, very great responsibility themselves, in my opinion (Principal 2).

As the pedagogic leader, the principal is responsible for ensuring that research and proven experience take place at school; however, this issues places pressure on principals from two sides. Because research is viewed as difficult and complicated, on one hand, the authorities are viewed as responsible for it, but on the other hand, the teachers themselves must actually take on the responsibility. However, one can note that in Sweden, unlike in many other countries, there is a lack of internal research in schools. At the same time, the results from external research show that it is difficult to make research a natural part of work in primary and secondary schools. That is one reason the state has established the School Research Institute. A further complicating aspect of this dilemma is that the principals locate research and scientific findings in the universities and do not think that there might be a locally based opportunity for research in their own schools:

However, of course, it's difficult, and it feels big and [...] sometimes very academic (Principal 4).

\section{Category 3. Research requires internal trust.}

The principals believe that applying the research basis in schools requires a collective effort; that is, everybody must in one way or the other participate when research findings are being implemented or when teachers in the schools are supposed to produce research (Level 2). Furthermore, the principals say in the interviews that if the teachers who are most trusted among their colleagues do not think that research is important, it will be impossible to perform research work:

... I think we need some form of trust in our activities, that the others must have trust in those who are doing research (Principal 5).

A consequence of this opinion is that the principals think that a teacher or teachers who will conduct research must first be considered legitimate by the staff; this is considered more important than having the necessary competence required to assimilate research results, put research into practice or conducting research of their own. These statements imply that teachers are not recruited on the basis of competence but on whether their colleagues view them as legitimate.

The principal's role on the whole is, as I said, pedagogical leader. Is that based on research, then? To initiate and also to organise, I think the whole school then. There you must engage the development group, the management group, or whatever you call it (Principal 7). 
Category 4. Research as necessary for quality improvement

The data contain frequent statements on how important research in schools could be if it is handled the right way, even if there is uncertainty about what such research would imply. This means that the lack of research competence at all levels of the school organisation causes teachers to miss an aspect of academic competence that other academically educated professional groups have. Consequently, teachers' professionalism has suffered (Level 3):

The professionalism is not quite there yet. We might need to raise it a bit (Principal 2).

The principals also make a connection between research and greater professionalism when they comment that teachers and principals must be considerably more analytical and reflective about what is happening during educational activities. They recurrently note that issues concerning e.g., insufficient goal fulfilment among certain pupils must be analysable and understandable if relevant measures are to be made. A part of this is also ensuring the use of highly precise language manages to convey clear descriptions at a detailed level.

... If we are going to see why Kalle did not get the mark E [...], did not reach that level, we must take a close look at the details: Where did it go wrong? Where did we lose him? Where did we go in the wrong direction? Because somewhere along the line we chose a direction that has sort of affected the outcome of what we do. And there it's a bit tricky because then we have to speak the same language and everything has to be documented and it must stand for the same thing. That's the way it is, it's a difficult task, but we have begun, I think; it feels somehow as if there is greater awareness of this today (Principal 2).

This category also contains the principals' statements about the level of research that they believe could be integrated into activities that can deepen and broaden the teachers' professionalism and promote analytical and reflection competences. Furthermore, research-based tools are needed to assess pupils who do not attain the goals and to try out new forms of teaching that are adapted to these pupils' needs. The research basis is important for the principals in this respect, and they seem to see that it might also help to improve the quality of both teaching and learning.

It is important to the principals that the research conducted in schools be of current interest and relevant to what characterises the school as an institution:

However, if it's going to work in addition to that, I think you must feel that it's something important you are doing research on. That it's something that concerns you (Principal 2).

The importance of proximity to practice and the idea that the research should affect practice are relatively common among the interviewed principals. There is an explicit fear that research will fall outside the core activities. The principals also emphasise that there must be clear relationships between the research and what the research is for. 
Category 5. Research as a natural part of the organisation of primary and secondary education

Only principal 4 offers a more reflective, detached conception of what is meant by research-based education. A reflective conception indicates an established perspective formed from the outside, where distance and dialogue are guidelines for a description that may be said to be holistic. This implies that it is not fruitful to talk about research-based education in primary and secondary education only. Research on and in schools must permeate the entire education system and should include studies conducted at the universities and at the political level (Level 3):

... to have something that felt that this is municipality $\mathrm{X}$ and the university ... or we'll do this together (Principal 4).

The interpretation of Principal 4's statements emphasises that all of the parts and levels of a research-based education in a school must have a shared view of how such work can be implemented. All parts of the organisation must take an interest in, understand and together (via clear communication), be able to handle both the consumption and the production aspects of research within the framework of education:

Yes. I think the goal fulfilment would increase. And that we would strengthen...we would strengthen the person who works in a preschool or a school. A teacher, to use that expression, I think so (Principal 3).

I think it will mean that we who work in education will be more certain of what it is we are doing. To put it into words, connect it to different types of research (Principal 5).

5.2 The second research question: What is proven experience in primary and secondary schools according to the principals in such schools?

Unlike the responses regarding the implications of research-based education, the analysis and results of this research question are not as complex and varied. The interview answers reveal that the principals have not been that much interested in the meaning of this concept. None of the principals mentioned the similar concept of evidence-based education in this context. Instead, the principals in this part of the study have an everyday conception of proven experience, but it does not resemble the definitions in the policy documents that the Swedish National Agency for Education presents or that the research community embraces. Because the principals had difficulties developing their answers about the concept of 'proven experience' it was only possible to create two categories under this research question. The results show that proven experience as a concept is conceived in two qualitatively different ways: Proven experience as private professional experience and Proven experience when we know that it works.

Category 1. Proven experience as private professional experience.

A widespread opinion among the principals is that proven experience is the same as having achieved something as part of teaching on some occasion (Level 1). 
I mean, I imagine that it's based on my own experiences in the first place, where I have tested my experiences in practice, so to speak (Principal 8).

Proven experience. You can say that all teachers who work have that. They test (Principal 1).

... about proven experience, I thought, 'That's what we are doing' (Principal 5).

Category 2. Proven experience when we know that it works.

This category contains the conception that proven experience denotes the type of teaching that teachers know will lead to good results or to established goals. Without the existence of or reference to research, goal fulfilment serves to characterise the proven experience (Level $1)$ :

... but I do so because I know that it works (Principal 2).

Both of these categories are characterised by everyday knowledge of one of the principal concepts in the new Swedish Education Act. This characterisation implies that the principals have no better understanding of this concept than people in general have. Such conceptions are unreflective, and the principals take for granted that they have 'proven experience' if they have worked as principals or teachers for a long time.

\section{Conclusions}

The results of the study shows that principals in Swedish primary and secondary schools are poorly or not at all prepared to provide education based on research and proven experience. The results also show that philosophers and pedagogues have definitions of 'research-based' and 'proven experience' that differ from what occurs within the framework of primary and secondary schools. On the whole, one can conclude that if Swedish primary and secondary schools are required to base their practices on research and proven experience, they have a long way to go before this will be possible; the knowledge among principals is too weak and differentiated for the act to be of any importance for improving the quality of education. This conclusion is particularly relevant for Sweden, but in the light of the existing research in the area, it may also be an international problem. One exception might be Finland, where they have taken a systematic approach to preparing for an education based on research and proven experience through teacher education programmes' clear demands for research and a research basis (cf. Toom, et al., 2008; Kansanen, 2014). Pertti Kansanen notes:

The most important feature is that teachers are able to reflect on their own work and change and develop their own practice according to practitioner research (Kansanen, 2014. p. 290).

In the conclusions that Finnish researchers drew about the success of their education system in the OECD/PISA investigations, nobody dared to state directly that research-based teacher education was the decisive factor; nor can we conclude in our study that practitioner research is undergoing development in the Swedish schools. However, we will claim that compared 
with other professional groups of academics, it seems natural that the education field should have a research basis and proven experience as a self-evident point of reference. Successful professions (e.g., physicians, lawyers, journalists, nurses, occupational therapists and physiotherapists) have a clear foundation in clinical research for their practice. School principals and teachers must also acquire this status if the quality of education is to improve and the teaching profession is to strengthen.

The results of this study shows the importance of understanding the consequences of something as uncommon as a national law that all teaching and learning in all schools should be based on research and proven experience. The Swedish government has expressed its trust that a top-down perspective will be effective and that such legislation will prompt schools to base their practices on scientific knowledge. If this national strategy is successful in increasing the quality of teaching and learning and accordingly improving school outcomes, several countries around the world will follow it. For that reason, it is of great importance to describe and understand the conceptualisations of a school based on research and proven experience.

Finally, this study raises three important questions: 1. Should the state (as in Sweden) take the responsibility for managing research in schools and among teachers, or should the teachers themselves take that responsibility and initiate such changes in teacher education programmes? 2. Is it possible to see any effect of research-based best practices on pupils' performances? 3. Does education (and consequently, teaching and teacher training) require a specific research concept that differs from the academies, definition of research and proven experience?

\section{References}

Aggarwal, J. C. (2007). Theory \& Principles of Education. New Dehli: Vikas publ. House.

Bengtsson, J. (2013). With the Lifeworld as Ground: Introduction to the Special Issue. An Outline of the Gothenburg Tradition of the Lifeworld Approach. Indo-Pacific Journal of Phenomenology, 13, 1-9.

Bengtsson, J., \& Kroksmark, T. (1994). Allmänmetodik Allmändidaktik. Lund: Studentlitteratur.

Bryk, A. S., Gomez, L. M., Grunow, A., \& LeMahieu, P. G. (2015). Learning to Improve. How America's Schools Ca Get Better at Getting Better. Cambridge, Massachusetts: Harvard Education Press

Cazden, C. B. (1986). Classroom discourse. In M. C. Wittrock (Ed). Handbook of Research on Teaching. New York: Macmillan Publ. company (Third Edition).

Cochran-Smith, M., \& Zeichner, K. M. (Eds.). (2005). Studying teacher education: The report of the AERA panel on research and teacher education. Washington, D.C.: AERA and Lawrence Erlbaum. 
Cochran-Smith, M., Feiman-Nemser, S., McIntyre, D. J., \& Demers, K. E. (Eds.). (2008). Handbook of research on teacher education: Enduring issues in changing contexts (3rd ed.). New York: Routledge.

Darling-Hammond, L. (2010). What we can learn from Finland's successful school reform? National Education Association: http://www.nea.org/home/40991.htm (04-03-2014)

Dewey, J. (1897). My Pedagogic Creed. School Journal, 54, 77-80.

Dewey, J. (1929/1983). Experience and Nature. In The Later Works, (vol 5). (J. A. Boyston (Ed.) Carbondale: Southern Illinois University Press.

Dewey, J. (1983). Democracy and Education. In The Middle Works (vol. 9) (J. A. Boyston (Ed.) Carbondale: Southern Illinois University Press.

DN (2015). Vi måste bli överens om grunderna för skolpolitiken. Debattartikel i Dagens Nyheter 5 januari, 2015.

Education Act (2010:800). Stockholm: Utbildningsdepartementet.

Elliott, J. (2001) Making evidence-based practice educational. British Educational Journal, 27(5), 555-574. http://dx.doi.org/10.1080/01411920120095735

Fixsen, D. L., S.F., Blasé, K. A., Friedman, R. M., \& Wallace, F. (2005). Implementation Research: A Synthesis of the Literature. Tampa; FL: University of South Florida, Louis de la Parte Florida Mental Health Institute, The National Implementation Research Network

Gadamer, H. G. (1996). Truth and Method. London: Sheed \& Ward.

Hammersley, M. (1997). Educational research and teaching: a response to David Hargreaves' TTA lecture. British Educational Research Journal, 23(2), 141-162.

Hargreaves, D. H. (1996). Teaching as a research-based profession: Possibilities and prospects. The teacher training agency annual lecture 1996. Retrieved from https://eppi.ioe.ac.uk/cms/Portals/0/PDF\%20reviews\%20and\%20summaries/TTA\%20H argreaves $\% 201$ ecture.pdf

Hargreaves, D. H. (1999). The knowledge creating school. British Journal of Educational Studies, 47(2), 122-144.

Hegender, H. (2010). Mellan akademi och profession. Hur lärarkunskap formuleras och bedöms $i$ verksamhetsförlagd lärarutbildning. Linköping University: Studies in Pedagogic Practices No 12

Heidegger, M. (1927). Sein und Zeit. Tübingen: Max Neimeyer verlag.

Hirsh, Å. (2013). The Individual Development Plan as Tool and Practice in Swedish Compulsory school. Jönköping University: Dissertation No 20.

Janesick, V. (1998). The Dance of Qualitative Research Design. Metaphor, Methodolatry, 
and Meaning. In N. K Denzin \& Y. S. Lincoln, Strategies of Qualitative Inquiry. Thousand Oaks: Sage Publications.

Jason, P. (2012). What is Education? Chicago: Chicago University Press.

Johansson, T., \& Kroksmark, T. (2004). Teachers' intuition-in-action: how teachers experience aktion. Reflective Practice, 5(3), 357-381.

Kansanen, P. (2014). Teaching as a Master's Level Profession in Finland: Theoretical Reflections and Practical Solutions. In O. McNamara et al (Eds). Workplace Learning in Teacher Education. Professional Learning and Development in Schools and Higher Education 10. Dordrecht: Springer.

Kommittédirektiv 2014:7. (Committee remit). Inrättande av ett skolforskningsinstitut. Stockholm: Utbildningsdepartementet

Kroksmark, T. (1995). Teaching and Teachers" "Didaktik". Outlines for a phenomenographic description of teachers' teaching competes. Studies in Philosophy and Education, 14(4), 365-382.

Kroksmark, T. (1996). How did Jesus teach? The evangelists' descriptions of the teaching methodology of Jesus. Scandinavian Journal of Educational Research, 40(2), 103-135.

Kroksmark, T. (2011). Den tidlösa pedagogiken. Lund: Studentlitteratur.

Kroksmark, T. (2014). The stretchiness of learning. The digital mystery of learning in one-to-one environments in schools. Education Information Technology. New York: Springer Verlag.

Kvale, S. (1983). The Qualitative research interview - A phenomenological and a hermeneutical mode of understanding. Journal of Phenomenological Psychology, 14, 171-196.

Kvale, S. (1994). Ten standard objections to qualitative research interviews. Journal of Phenomenological Psychology, 25, 147-173.

Kvale, S. (1997). Den kvalitativa forskningsintervjun. Lund: Studentlitteratur.

Lincoln, Y. S., \& Denzin, N. K. (2004). Turning Points in Qualitative Research: Tying Knots in a Handkerchief. Oxford: Alta Mira Press

Marton, F. (1981). Phenomenography - Describing Conceptions of the World Around us. Instructional Science, 10, 177-200. http://dx.doi.org/10.1007/BF00132516

McLaughlin, C. (2004). Practitioner research and enquiry. In C. McLaughlin, K. Black-Hawkins, \& D. McIntyre (Eds.). Researching Teachers, Researching Schools, Researching Networks: A Review of the Literature. Cambridge: University of Cambridge Faculty of Education July 2004. Merriam Webster (m-w.com). Encyclopædia Britannica. Retrieved 24 February 2014.

Nef, N. (2014). Basic meaning of education. Essay for Education. 
http://www.scribd.com/doc/ 175747047/Essay-for-Education (03-03.2014).

OECD (2014). PISA 2012 Results: What student know and can do, Students performance in mathematics, reading and science. (Vol 1). Revised edition, February 2014. PISA, OECD Publishing.

Polany, M. (1966). The Tacit Dimension. London: Doubleday \& Co.

Proposition (2009/10:165). Den nya skollagen - för kunskap, valfrihet och trygghet. Stockholm: Utbildningsdepartementet.

Rapp, S. (2010). Headteacher as a pedagogical leader: A comparative study of head teachers in Sweden and England. British Journal of Educational Studies, 58(3), 331-349. http://dx.doi.org/10.1080/00071001003752229

Rapp, S., \& Kroksmark, T. (2017). Teachers' understanding of the concept of research-based teaching. (Submitted).

Rudduck, J. (1992). Universities in Partnership with Schools. In M. Fullan \& A. Hargreaves (Eds). Teacher Development and Educational Change. London: The Falmer Press.

Sahlberg, P. (2009). Educational Change in Finland, in A. Hargreaves, M. Fullan, A. Lieberman, and D. Hopkins (Eds.), International Handbook of Educational Change. Kluwer Academic Press. New York: Springer Verlag.

Sahu, B. (2002). The New Educational Philosophy. New Delhi: Sarup \& Sons. SERC (2014). http://ctserc.org/s/index.php?option=com_content\&view=section\&id=8\&Itemid=28 (2014.02.27)

SEDL (2016). http://www.sedl.org/pubs/sedl-letter/v15n01/2.html

Stenhouse, L. (1975). An Introduction to Curriculum Research and Development. London: Heinemann Educational Books.

Stenhouse, L. (1981). What counts as research? British Journal of Educational Studies, 29(2), 103-114. http://dx.doi.org/10.1080/00071005.1981.9973589

Swedish National Agency for Education (2011). Curriculum for the compulsory school, preschool class and the recreation centre.

Swedish National Agency for Education (2014). Vetenskaplig grund, beprövad erfarenhet och evidens. http://www.skolverket.se/skolutveckling/forskning/vetenskaplig-grund-och-beprovad-erf arenhet/vetenskaplig-grund-beprovad-erfarenhet-och-evidens-1.189565 (2014.02.27)

Toom, A., Krokfors, L., Kynaslahti, H., Stenberg, K., Maaranen, K., Jyrhämö, R., Byman, R. \& Kansanen, P. (2008). Exploring the essential characteristics of research-based teacher education from the viewpoint of teacher educators. Researchgate: http:// www.researchgate.net/publication/242592694_Exploring_the_essential_characteristics_ of_research-based_teacher_education_from_the_viewpoint_of_teacher_educators 


\section{Macrothink}

Valencia, S., Martin, S., Place, N., \& Grossman, P. (2009). Complex interactions in student teaching: lost opportunities for learning. Journal of Teacher Education, 60(3), 304-322.

van Manen, M. (1990). Researching lived experience. Ontario: The University of Western Ontario. Zhang, Y. (2008). Classroom Discourse and Student Learning. Asian Social Science, 4(9), 80-83. http://dx.doi.org/10.5539/ass.v4n9p80

Wibeck, V. (2000). Fokusgrupper. Om fokuserade gruppintervjuer som undersökningsmetod. Lund: Studentlitteratur.

\section{Notes}

Note 1. This could be exemplified by international comparisons of school outcomes; for instance, PISA, where results are reported as a ranking list or 'league table' of participating countries.

Note 2. In January 2015, the Swedish Minister of Education argued in a debate article (DN, 2015) that political parties must stop fighting and agree on the education policy. The minister stated that governing documents 'shouldn't be repainted every time the colour of the government is changed' and argued that changes in the educational system must be anchored in contemporary research. This debate article indicates that regardless of the government's 'colour', educational policy is largely based on ideology, not research

\section{Copyright Disclaimer}

Copyright for this article is retained by the author(s), with first publication rights granted to the journal.

This is an open-access article distributed under the terms and conditions of the Creative Commons Attribution license (http://creativecommons.org/licenses/by/3.0/). 